\title{
People interviewed
}

This is a list of those people interviewed by Michele Abendstern whose testimony relates wholly or in part to the years 1973-90. The brief biographical notes given here are not intended to be complete. They are designed to focus mainly on people's connections with the University during that time, and sometimes on their activities immediately after leaving the University or in the interval between two periods at the University.

Aaronovitch, David. Journalist and broadcaster; columnist of The Independent and lately of The Guardian. Undergraduate, Department of History, 1974-78; participant in University Challenge, 1975. NUS Vice-President (Services), 1976-77; NUS President, 1980-82.

Ahmed, Sarah. Undergraduate, Faculty of Law, 1984-87.

Beswick, Frederic Bakewell (Bill). Doctor and administrator. Associate Dean, then Executive Dean, Faculty of Medicine, 1969-79; Bursar, 1979-84; Hon. Ll.D. (Manc.), 1986. Chairman of Salford Health Authority, 1984-94.

Boucher, Joyce. Schoolteacher and life-long resident of Fallowfield, active in the Civic Society. Graduate in English, 1949.

Brazier, Margot (born Margot Jacobs). Authority on torts and medical law; Chairman of the NHS Retained Organs Commission. Taught in Faculty of Law from 1971; Professor of Law from 1989.

Bromley, Peter. Authority on family law. Professor of Law and three times Dean of the Faculty, 1965-86. Pro-Vice-Chancellor, 1977-81. Member of the UGC, 1978-85.

Buckley, Michael. Administrator. Member of Registrar's Department from 1966; responsibilities included the Business School and the Academic Staffing Office; Deputy Registrar, with responsibility for Court and Council, 1986-94. Honorary Lecturer in Overseas Studies.

Burchell, Robert. Historian of the United States, also famous for generous hospitality. Taught in Department of American Studies, 1965-96; Head of Department, 1989-94; Professor of American Studies, 1991-96. Sometime elected member of Senate. Chairman, British Association for American Studies, 1989-92; Director of the Eccles Centre for American Studies in Britain, at the British Library, 1991-2001. FRSA, 2001.

Cameron, Harry. Electrician and engineer. Joined Electrical Services Department, 1951; apprentice, subsequently electrician, planned maintenance engineer, Assistant Electrical Engineer (1978), Electrical Engineer (1981) 
and Assistant Chief Engineer (1985-88).

Cameron, Ian. Administrator. Personnel Officer, later Personnel Manager, 1977-2000.

Carling, Ellen B. Secretary, from 1964 Personal Assistant, to the Professors of Astronomy (Professors Kopal, Kahn and Dyson), 1954-95

Cox, [Charles] Brian. Poet, critic and writer on education. Professor of English Literature, subsequently John Edward Taylor Professor, 1966-93; Dean of the Faculty of Arts, 1984-86; Pro-Vice-Chancellor, 1987-91. Coeditor of Critical Quarterly from 1959; of Black Papers on Education, 1969-77; Chairman, National Curriculum English Working Group, 1988-89. CBE, 1990; FRSL, 1993.

Cummings, Patricia. Librarian, particularly concerned with the Manchester Medical Collection. Joined the staff of the Medical Library as Library Assistant, 1950; later Assistant Librarian; ALA, 1971; member of the Department of Information Resources, John Rylands University Library. Hon. MA (Manc.), 1997.

Davies, Rodney. Radio astronomer. Worked with the Radio Astronomy Group at the Jodrell Bank outstation from 1953; Professor of Radio Astronomy, 1976-97; Director of the Nuffield Radio Astronomy Laboratories, 1988-97. President of the Royal Astronomical Society, 1987-89. FRS, 1992; CBE, 1995.

Denton, Jeffrey. Historian of the medieval Church. Taught in Department of History, 1965-97; Professor of Medieval History, 1988-97; Research Professor, 1997-2000.

French, Elizabeth (Lisa). Archaeologist and academic administrator. Warden of Ashburne Hall, 1976-89; afterwards Director of the British School at Athens.

Griffith, John. Academic lawyer. Emeritus Professor of Public Law in the University of London (LSE). Chancellor of the University of Manchester, 1986-93. Hon. Ll.D. (Manc.) 1987. Founder member of the Council for Academic Freedom and Democracy. FBA 1977.

Haddy, Pamela. Clerical supervisor. Joined staff of Registrar's office as Clerical Assistant, 1949; Supervisor of the Awards Office, 1963-93.

Hallett, Christine. Lecturer in Nursing and historian. Undergraduate, Department of Nursing, 1981-85; district nurse and health visitor, Oldham Health Authority and Bolton Health Authority, 1985-89; part-time student, Department of History, 1985-93; research assistant in Department of Nursing, 1989-93; part-time Lecturer, later Lecturer, in Nursing from 1993. Ph.D. in Nursing, 1995; Ph.D. in History, 2002.

Harris, Martin (afterwards Sir Martin). Vice-Chancellor and Professor of Romance Linguistics, 1992- . Member of the UGC, 1983-87; Chairman of the CVCP, 1997-99. CBE, 1992; knighted, 2000.

Hunt, Christopher. Librarian. Sub-Librarian, Social Sciences, Manchester University Library (later John Rylands University Library of Manchester), 1968-74; University Librarian, James Cook University of North Queensland, 1974-81, and of La Trobe University, Melbourne, 1981-85; Librarian, 
London School of Economics and Political Science, 1985-91; University Librarian and Director of the John Rylands University Library of Manchester, 1991-2002.

Imber, Kee Kok (born Kee Kok Lee, writes as Kee Kok Lee). Philosopher, with particular interests in environmental philosophy. Taught in Department of Philosophy, 1966-99; retired as Reader.

Jones, Peter. Taught in Department of Electrical Engineering, later School of Engineering, 1963-97; retired as Senior Lecturer. Elected member of Senate. Chairman of the Electronics Computer- Aided Design Initiative, 1984.

Kemp, Sarah (born Sarah Bentley). Managing Director, Explore International (a subsidiary of National Geographic and a distributor of documentary films); formerly Managing Director, Hulton Getty Picture Collection and President, Archive Films and Photos (New York). Undergraduate, Department of History, 1975-78. FCMA, 1994; FRSA, 2000.

Kent, Harry. Administrator. Joined Bursar's Department, 1947; Establishment and Superannuation Officer, retitled Deputy Bursar in Charge of Personnel, 1971-82.

Kenyon, George (afterwards Sir George). Engineer, industrialist and banker. Member of Council, 1960-88; Treasurer, 1970-72, 1980-82; Chairman, 1972-80; Chairman of Vuman Ltd., 1982-88. Hon. Ll.D (Manc.), 1980. Knighted, 1976.

Kitchen, Kenneth. Administrator. Joined Registrar's Department, 1965; Deputy Registrar, 1971-79; Registrar, 1979-94. Honorary Lecturer in Government. Co-organiser of the Northern Universities Administrative Training Programme (first run 1971); Administrative Training Officer to the CVCP, 1975-77; Business Secretary to the Conference of Registrars and Secretaries (later the Association of Heads of University Administrations).

Knowles, Vincent. Administrator. Registrar, 1951-79; subsequently Schools Liaison Officer. Special Lecturer in Greek and Latin. Hon. Ll.D. (Manc.), 1979. OBE, 1977.

Leitch, Diana. Librarian. Joined staff of John Rylands University Library of Manchester, 1973; subsequently Sub-Librarian, Science; Head of Acquisitions; and Head of Information Services. Deputy Librarian and Assistant Director since 1995.

Lowe, Peter. Historian of diplomacy in the Far East. Taught in Department of History from 1965; retired from full-time work as Reader, 2001. Elected member of Senate and of Standing Committee of Senate. Officeholder (on many occasions) in Manchester branch of AUT.

McCulloch, Walter. Chief Technician, University Library, Photographic Section. Member of the University staff, 1935-81; sometime Chairman of William Kay House.

McFarlane, Jean (afterwards Baroness McFarlane of Llandaff). Pioneer in nursing education. Senior Lecturer and Head of Nursing, Department of Social and Preventive Medicine, 1971-73; Senior Lecturer and Head of 
Department of Nursing, 1973-74; Professor of Nursing, 1974-88. Member of Royal Commission on the National Health Service, 1976 -79. Life peer, 1979. Hon. M.Sc. (Manc.), 1979; Hon. D.Sc. (Manc.), 1998.

McKenna, Gerard. Administrator. Joined Registrar's Department, 1967; Secretary to the Faculty of Medicine, 1970-80; Assistant Registrar in charge of the Accommodation Office, 1982-97. Tutor and later Vice-Warden of Allen Hall, 1967-78.

Mays, Wolfe. Philosopher. Taught in Department of Philosophy, 1946-79; retired as Reader. Officeholder (on many occasions) in Manchester branch of AUT.

Moore, Stuart Alfred (Sam). Econometrician. Lecturer, later Senior Lecturer, in Economic Statistics, 1964-92; Robert Ottley Professor of Quantitive Studies, 1992-97. Dean of the Faculty of Economic and Social Studies, 1980-83; Pro-Vice-Chancellor, 1985-90; Acting Vice-Chancellor, 199092; Deputy Vice-Chancellor, 1990-96.

Mulholland, Maureen (born Maureen O'Brien). Legal historian, also concerned with law and medicine. Taught in the Faculty (later School) of Law from 1964; now Honorary Lecturer.

Newcomb, Edgar (Eddie). Administrator. Registrar and Secretary, 1995- . Chairman of the Association of Heads of University Administration, 1998- . OBE, 2002.

North, Geoffrey. Geographer. Taught in Department of Geography, 195493; retired as Senior Lecturer. Adviser in the Central Academic Advisory Services from 1972. Chairman and member of numerous University committees (at one time between thirty and forty). Hon. MA (Manc.), 1996.

Ogden, Rev. Eric. Administrator, clergyman, and transport historian. Assistant Accountant, Bursar's Department, 1968-89, responsible for academic salaries and halls of residence accounts, and later for research grants; Treasurer to the Chaplaincy, 1970-79. Took North-West Ordination Course, 1973-76.

Pailin, David. Philosopher and theologian; Methodist minister. Taught in Faculty of Theology from 1966; Dean, 1979-80. Professor of the Philosophy of Religion, 1994-2001.

Parry, Geraint. Political theorist and writer on politics. Taught in Department of Government, 1971-74; Edward Caird Professor of Politics, University of Glasgow, 1974-76; Professor of Government, later W.J.M. Mackenzie Professor of Government, 1977-99.

Perera, Katharine. Member of the Department of Linguistics and of the University's Senior Management Team. Postgraduate student, Department of Linguistics, 1972-74; rejoined Department as Lecturer, 1977; Professor of Educational Linguistics (first in United Kingdom), 1991- ; Pro-ViceChancellor, 1994-2000; Senior Pro-Vice-Chancellor, 2000.

Prothero, Iorwerth (Iori). Historian, especially of radical movements in the early nineteenth century; taught in Department of History from 1964. 
Retired from full-time work as Senior Lecturer, 2001. Elected member of Senate and of Standing Committee of Senate. Officeholder (on many occasions) in Manchester branch of AUT.

Purdy, David. Economist, especially interested in the labour market and the social security interface. Taught in Department of Economics, 1968-94 (subsequently transferred to Department of Social Policy and Social Work). Now Senior Lecturer.

Radcliffe, Philip. Communications Officer (retitled Director of Communications, 1978), 1970-95. Honorary Lecturer in Adult Education, 1974-95.

Ratcliffe, Frederick. Librarian. Librarian, University of Manchester, 1965-80 (Director of the John Rylands University Library of Manchester, 1972-80); Librarian, University of Cambridge, and Fellow of Corpus Christi College, 1980-94 (subsequently Life Fellow); Parker Librarian, 1995-2000. CBE, 1994.

Rhodes, Gay. Secretary in the Dean's office, School of Medicine, 1968-79; Personal Assistant to the Dean, 1979-99.

Richardson, David. Administrator. Joined Registrar's Department, 1967; Assistant to the Vice-Chancellor (Arthur Armitage), 1970-74; Secretary to the Faculty of Arts, 1974-79; Deputy Registrar, 1979-94; Academic Secretary, 1994-97; subsequently concerned with the establishment of a University Foundation, to pursue the possibility of fundraising in North America.

Richardson, James. Pseudonym of a student in the 1970s.

Richmond, Mark (afterwards Sir Mark). Bacteriologist and academic statesman. Vice-Chancellor and Professor of Molecular Microbiology, 1981-90. Chairman of CVCP, 1987-89; Chairman, Committee on Microbiological Food Safety, 1989-91; Chairman of SERC, 1990-94; Group Head of Research, Glaxo Holdings, 1993-95; Member of the School of Public Policy, University College London, 1996- . Hon. Ll.D (Manc.), 1990. FRS, 1980; knighted, 1986.

Rose, Michael. Social historian of the nineteenth and twentieth centuries. Taught in Department of History from 1962; Head of Economic History, 1982-89; Professor of Modern Social History, 1989-99.

Smith, Ian. Civil engineer. Taught in Department of Engineering (later School of Engineering) from 1967; Professor of Geotechnical Engineering, 1984- .

Tallentire, Alan. Pharmacist and sports enthusiast. Taught in Department of Pharmacy, 1953-96; Professor of Pharmacy, 1979-96.

Trinci, Tony. Mycologist. Barker Professor of Cryptogamic Botany, 19812001; first Chairman of the School of Biological Sciences, 1986-90.

Turnberg, Leslie (afterwards Lord Turnberg of Cheadle). Physician and specialist in gastroenterology. Taught in Medical School from 1968; Professor of Medicine, 1973-97, particularly concerned with developing the academic community at Hope Hospital, Salford; Dean of the Faculty of Medicine, 1986-90. 
Tye, Frederick. Headmaster and trainer of headteachers (Director of the North West Educational Management Centre, 1972-81). Member of Court, 1962-98, and of Council, 1967-92, particularly concerned with University-Union relations, disabled access, and car parking. Hon. M.Ed. (Manc.), 1993. CBE, 1980.

Vernon, James. Historian, specialising in British history of the nineteenth and twentieth centuries. Undergraduate, School of Politics and Modern History, 1984-87; postgraduate, Department of History, 1987-91.

Walsh, Joan. Mathematician, with special interests in computing. Taught in Department of Mathematics, 1963-97; Professor of Numerical Analysis, later of Applied Mathematics, 1974-97; Pro-Vice-Chancellor, 1988-94. Member of National Computer Board, 1981-86.

Welland, Dennis. Literary scholar and academic administrator. Taught in Department of American Studies, 1962-83; Professor of American Literature, 1965-83; Dean of the Faculty of Arts, 1976-78; Pro-Vice-Chancellor, 1979-83; Acting Vice-Chancellor, 1980-81. Hon.Ll.D. (Manc.), 1992. Chairman, British Association of American Studies, 1980-83. Died 2002.

Williams, Olwen. Administrator. Welfare Officer in the Establishment Unit, Bursar's (later Registrar's) Department, 1971-89. Founder of Retired Staff Association.

Willmott, John. Physicist. Professor of Nuclear Structure, later of Physics, 1964-89; Director of the Physical Laboratories, 1967-89; Pro-ViceChancellor, 1982-85; Adviser to Vice-Chancellor on Research Exploitation, 1988-93. CBE, 1983.

Wilmers, George. Lecturer in Department of Mathematics from 1970. Elected member of Senate and of Court.

Young, Margaret L.M. French scholar; specialist in Renaissance literature. Taught in Department of French Studies, 1948-84; retired as Senior Lecturer. Adviser in the Central Advisory Service, 1972-78; Dean of the Faculty of Arts, 1978-80.

Zussman, Jack. Geologist. Professor of Geology, 1967-89; Dean of the Faculty of Science, 1980-81. President of the Mineralogical Society of Great Britain and Ireland, 1980-81. 